Int. J. Electrochem. Sci., 14 (2019) 2857 - 2873

\title{
Flow Path Optimization for a Typical 20 Cells Solid Oxide Fuel Cell Stack with Co- and Counter- Flow Arrangement Patterns
}

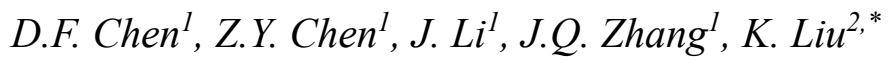 \\ ${ }^{1}$ School of Power and Energy, Jiangsu University of Science and Technology, Zhenjiang 212003, \\ China \\ ${ }^{2}$ School of Naval Architecture and Ocean Engineering, Jiangsu University of Science and Technology, \\ Zhenjiang 212003, China \\ *E-mail: dfchen01@163.com, kunliu@just.edu.cn
}

doi: $10.20964 / 2019.03 .40$

Received: 22 November 2018 / Accepted: 5 January 2019 / Published: 7 February 2019

This paper focuses on air and fuel flow path optimizations for a specific 20 cells modular stack operated in both co- and counter-flow arrangement patterns. Stack uniformity index is used to characterize air (or fuel) flow distribution quality among the piled 20 cell units. Standard deviation factor for the mass flow rates obtained by rib channels is adopted to present the flow distribution quality over each cell surface. Then, the effect of the geometric parameters, such as air and fuel manifold configurations, manifold radii, feed and exhaust header widths, on the flow distribution qualities within the specific stack design are studied to achieve the optimized choice for both co- and counter-flow arrangement patterns. Predicted result shows that the best counter-flow arrangement pattern for the 20 cells stack is that 2 in 3 out manifold configurations for both air and fuel flow paths. The best co-flow arrangement pattern for the 20 cells stack is that 2in3out manifold configuration for air flow path and 3in2out manifold configuration for fuel flow path. Proper fuel/air flow manifold radii and feed/exhaust header widths for different flow distribution qualities within the specific 20-cell stack are also provided.

Keywords: SOFC modular stack; calculated fluid dynamics; counter- and co-flows; rib channels.

\section{FULL TEXT}

(C) 2019 The Authors. Published by ESG (www.electrochemsci.org). This article is an open access article distributed under the terms and conditions of the Creative Commons Attribution license (http://creativecommons.org/licenses/by/4.0/). 